\title{
Craniometrical differentiation of gray brocket deer species from Brazil
}

\author{
Susana GONZÁLEZ ${ }^{1,2}$, Aline Meira BONFIM MANTELLATTO³ \& José Maurício BARBANTI \\ DUARTE $^{3}$
}

\begin{abstract}
${ }^{1}$ Genética de la Conservación, Departamento de Biodiversidad y Genética-Instituto de Investigaciones Biológicas Clemente Estable (IIBCE)-Ministerio de Educación y Cultura (MEC). ${ }^{2}$ Sección Genética-Facultad de Ciencias UdelaR, Montevideo, Uruguay. ${ }^{3}$ Núcleo de Pesquisa e Conservação de Cervídeos (NUPECCE), Departamento de Zootecnia, Universidade Estadual Paulista Júlio de Mesquita Filho (UNESP), Jaboticabal-SP, Brasil.
\end{abstract}

\begin{abstract}
The genus Mazama (brocket deer) constitutes successful adaptive radiation, with a wide distribution in the Neotropical region. However, the taxonomy and systematics of its species and subspecies is still controversial. The objective of this contribution was to carry out a comparative craniometric study of specimens deposited in Brazilian museums of $M$. gouazoubira $(\mathrm{Mg})$ and $M$. nemorivaga $(\mathrm{Mn})$, in order to characterize these cryptic species. We performed 36 measures on 87 skulls of adult specimens ( $M g=32$ females and 27 males; $M n=14$ females and 14 males). The sample was compared by analysis of variance and multivariate analysis of principal components and discriminant. In most cranial measurements, males and females of $M$. gouazoubira were $5 \%$ larger, with the exception of 3 measures: premolar-prosthion, basifacial axis, and least breadth between the orbits, that were larger in males and females of $M$. nemorivaga. This study showed significant differences between the two taxa that would validate the distinction of both species. To examine in more detail the dynamics of the variation of these two taxa it is necessary to increase the sample size in order to analyse them in a geographical and genetic context.
\end{abstract}

Key words: Craneometrical, gray brocket deer, Mazama gouazoubira, Mazama nemorivaga.

Resumen: Diferenciación craniométrica de las especies de corzuelas pardas de Brasil. El género Mazama constituye una exitosa radiación adaptativa, con una amplia distribución en la región Neotropical. Sin embargo, la taxonomía y sistemática sus especies y subespecies es todavía motivo de controversias. El objetivo de esta contribución fue realizar un estudio craneométrico comparativo de ejemplares depositados en museos de Brasil de $M$. gouazoubira $(M g)$ y $M$. nemorivaga $(M n)$, con el fin de caracterizar estas especies cripticas. Se tomaron 36 medidas en 87 cráneos de ejemplares adultos $(M g=32$ hembras y 27 machos; $M n=14$ hembras y 14 machos). La muestra se comparó mediante análisis de la varianza y análisis multivariados de componentes principales y discriminante. En la mayoría de las medidas craneanas los ejemplares machos y hembras de M. gouazoubira fueron un 5\% más grandes, con la excepción de 3 medidas: premolar - prosthion, eje basifacial y el ancho menor entre orbitas, que presentaron mayor tamaño en los ejemplares machos y hembras de $M$. nemorivaga. Este estudio permitió mostrar que existen diferencias significativas entre los dos taxa, que validarían la distinción de ambas especies. Para examinar con más detalle la dinámica de la variación de estos dos taxa es necesario aumentar el tamaño de las muestras y analizarlas en un contexto geográfico y genético.

Palabras clave: Craneometría, corzuelas grises, Mazama gouazoubira, Mazama nemorivaga.

\section{INTRODUCTION}

The genus Mazama Rafinesque, 1817 represent a successful adaptive radiation of South American deers, that has a wide distributional range in the Neotropical region, extending from the State of Vera Cruz in Mexico to central Argentina (from sea-level to $4,900 \mathrm{~m}$ a.s.l.; see Allen, 1915; Black-Decima et al., 2010; Rossi et al., 2010). The taxonomy of the genus is complex and controversial, concerning both the species as well as the subspecies systematics. Until 1850, only two species of Mazama were recognized. In 1878 Sir Victor Brooke performed a detailed review of this genus and recognized six species, but only four of them were well established. In 1898, Lydekker identified seven species, six of them clearly distinguishable. However, when Allen (1915) performed the first systematic review of the genus Mazama, he recognized 16 forms of 
red brocket deer and eight forms of gray brocket deer. During the decade of 1960, Cabrera simplified this scenario identifying two main groups and four species: a) Red brockets: Mazama americana (M. a. americana, M. a. rufa, M. a. sheila, M. a. zetta, M. a. zamora), Mazama rufina (M. r. rufina, M. r. briceni) and b) Gray brockets: Mazama gouazoubira (M. m. gouazoubira, $M$. g. murelia, M. g. tchudii, M. g. superciliaris, M. g. cita), and Mazama chunyi.

$M$. nemorivaga was firstly described by Cuvier in 1817, from a specimen from Cayenne, in French Guiana. Subsequently, Allen (1915) recognized this taxon within his gray brocket deer species group and restricted the geographical range of $M$. nemorivaga for individuals from the region of French and British Guyanas. MirandaRibeiro (1919), in his extensive taxonomic study of Brazilian deer, described a small species of gray brocket deer in the state of Rondonia and named it $M$. rondoni. However, Cabrera \& Yepes (1960) and Cabrera (1960) not recognized this species, proposing it as a synonym of $M$. gouazoubira superciliaris. In 1987, Czernay updates the taxonomy of Mazama and recognized six species: $M$. americana, $M$. gouazoubira, $M$. rufina, $M$. nana, $M$. chunyi and $M$. bricenii.

\section{Mazama gouazoubira}

The "gray brocket or brown brocket deer" (Mazama gouazoubira) is the most abundant deer in South America (Duarte, 1996), being classified by the IUCN Red List (2009) as a least concern. However, in Brazil, the regional classification of the species is variable, being considered as threatened in some states (e.g., Rio de Janeiro; Bergallo et al., 2000).

It is a small to medium sized species, with an average weight ranging from $11-25 \mathrm{~kg}$ and an average height of $50 \mathrm{~cm}$ (Duarte, 1998; Rossi, 2000). The general coloration of individuals varies from dark gray to reddish brown (Pinder \& Leeuwenberg, 1997). The submandibular and periophthalmic regions are lighter, light cream coloured. Most individuals have a white spot above the eyes, which characterizes the species and below the tail. They have large and rounded ears and non-branched antlers, characteristic of all species of the genus Mazama (Duarte, 1996; Duarte, 1998). The antlers are present only in males and have the form of a spike of 56.3 to $117.3 \mathrm{~mm}$ in length. They are conical or laterally compressed, straight or slightly curved medially, and parallel or slightly divergent from each other, and positioned at a sharp angle with respect to the dorsal surface of the skull. The burr contains elongated and more or less deformed tubercles of different sizes (Black-Decima et al., 2010).

The skull has a long rostrum that occupies $47-51 \%$ of the total length of the skull (Fig. 1). The premaxillaries are punctually united to nasals or completely separated from them by an anterior projected bar of the maxillaries. The lacrymal pit is shallow or moderately deep. The orbit is rounded or more or less squared, with a vertical diameter between 25.6 and $31.9 \mathrm{~mm}$. The auditory bulla is small but wide, with its greatest width ranging from 10.4 to $13.3 \mathrm{~mm}$; its ventral surface is adorned with crests or projections. The dental formula is $0 / 3 \mathrm{i} 0 / 1 \mathrm{c} 3 / 3 \mathrm{pm} 3 / 3 \mathrm{~m} \mathrm{x} 2=32$. Small upper canines can be seen in some adult specimens. The length of the maxillary tooth row ranges from 45.2 to $55.9 \mathrm{~mm}$ (Black-Decima et $a l ., 2010)$.

This species occupies dense and continuous forests to open savannahs with small patches of forests. It is an easily found species, occupying the Cerrado to the south of the Amazon River up to the north of Argentina and Uruguay (ÁvilaPires, 1959; Duarte, 1996; González \& Elizondo, 2010). This diversity of ecosystems and seasonal regimes can influence several aspects of their ecology (selection, habitat, diet, density and reproduction), in addition to their social behaviour, causing certain variations within and between populations. This species is relatively resilient; being capable to live in agroecosystems intermixed with small forest fragments (Pinder \& Leeuwenberg, 1997; Rodrigues et al., 2014, 2017). In the Amazonian region, it is probably replaced by Mazama nemorivaga, a hypothesis that has not been fully tested (Duarte, 1996; Rossi, 2000; Black-Decima et al., 2010; Rossi et al., 2010)

\section{Mazama nemorivaga}

The "Amazonian brown brocket deer" (Mazama nemorivaga) has a wide distribution and inhabit in many protected areas of Amazonian basin forests. Although this species is threatened by loss of habitat and local hunting (mainly for subsistence), it had been classified by the IUCN Red List (2016) as a least concern. However, we infer that it must be suffering a certain degree of threat since its habitat is being extensively altered by deforestation and agricultural activities, in addition to the hunting pressure that is the object (Rossi \& Duarte, 2016).

The Amazonian brown brocket deer is a small deer, about $15 \mathrm{~kg}$ average weight and $48 \mathrm{~cm}$ height (Rossi et al., 2010). The pelage of the head 


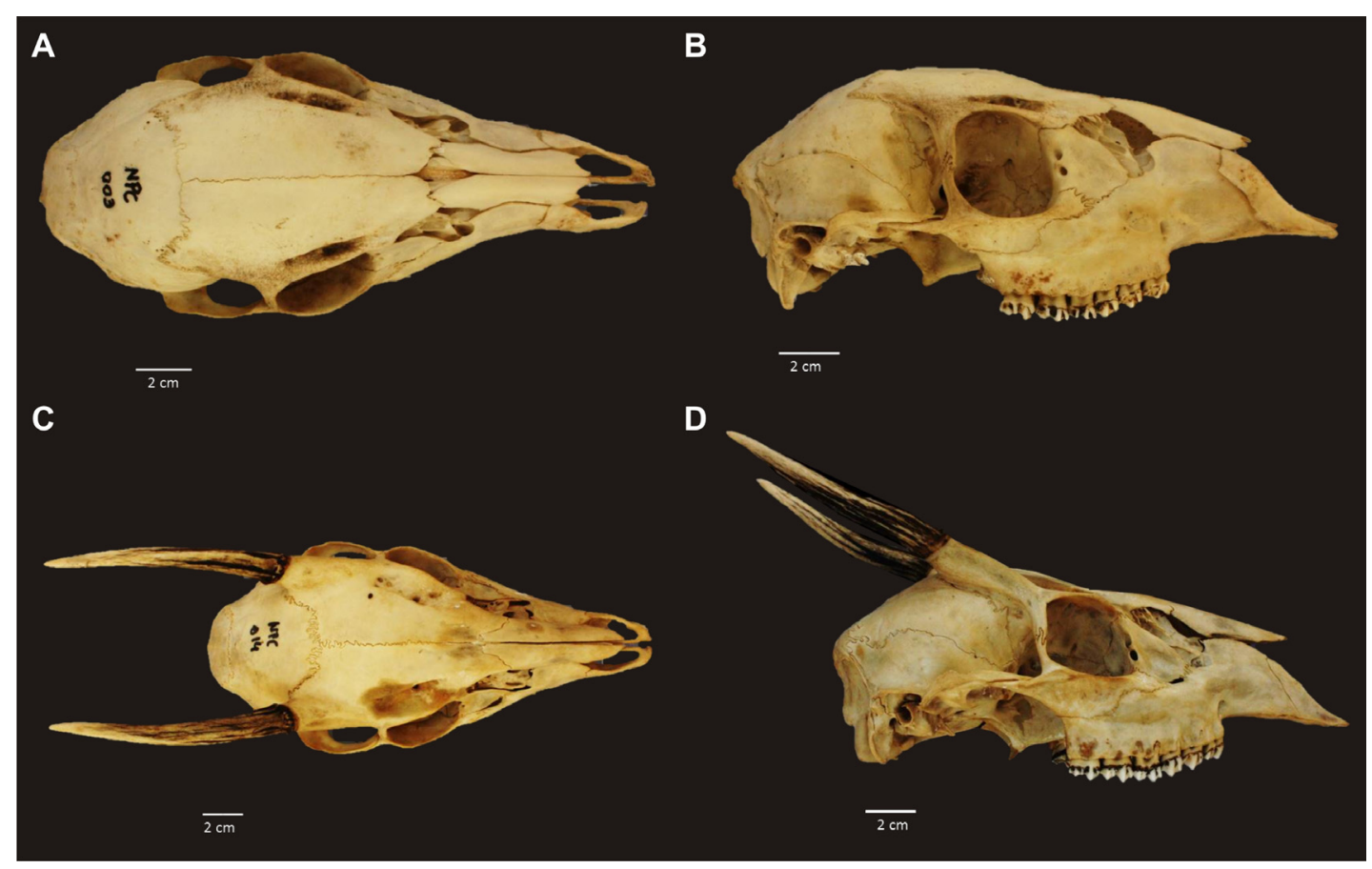

Fig. 1. Skull of an adult female (NPC 003) and adult male (NPC014) of Mazama gouazoubira. A) Dorsal view of adult female, B) Lateral view of adult female, C) Dorsal view of adult male, D) Lateral view of adult male.

exhibits a dark brown frontal tuft, tipped with black or not; small and barely defined buff spots on the edges of the upper lip; a whitish and not sharply defined spot on the anterior border of the chin, followed by dark buff and barely defined bands; and orange-brown inferior and superior orbital bands, not sharply defined, with yellow hairs mainly in the lateral areas. A diagnostic characteristic is the absence of the tarsal tuft. The adult males have spike-like antlers, ranging from 27.7 to $108.0 \mathrm{~mm}$ in length. Antlers are conical, usually slender, straight or slightly curved medially, and quite bent in relation to the dorsal surface of the skull; they may be parallel or slightly divergent between each other. The burr contains small spherical or elongated and more or less deformed tubercles (Rossi et al., 2010).

The skull has a long rostrum that corresponds to $47-52 \%$ of the total length of the skull (Fig. 2). The premaxillaries are usually separated from the nasals by an anterior projected bar of the maxillaries. The depth of the lachrymal pit varies among individuals; in some it is shallow, while in others it is deep. The orbit is large, with vertical diameter between 28.0 to $34.0 \mathrm{~mm}$, and may be rounded or more or less squared in shape. The auditory bulla is small and narrow, with its greatest width ranging from 8.2 to $11.4 \mathrm{~mm}$; its ventral surface is adorned with crests and small projections. Small upper canines are rarely seen in adult specimens. The dental formula is $0 / 3 \mathrm{i}$ $0 / 1 \mathrm{c} 3 / 3 \mathrm{pm} 3 / 3 \mathrm{~m} \times 2=32$. The length of the maxillary toothrow ranges from 46.2 to $53.2 \mathrm{~mm}$. The length of the maxillary toothrow ranges from 46.2 to $53.2 \mathrm{~mm}$ (Rossi et al., 2010).

Its geographical range is extended from Brazil, French Guiana, Suriname, Guyana, Venezuela, Colombia, Panama (Isla San José), Ecuador, Peru, and probably northern Bolivia (Rossi \& Duarte, 2008). In Brazil it is present in the states of Amazonas, Pará, Rondônia, Amapá, north of Mato Grosso, and northwest of Maranhão (Rossi, 2000). This species seems to be restricted to the Dense Ombrophilous Forests of the Amazonian Region and particularly in the State of Maranhão. It may also occur in the transitional areas between the Cerrado and Seasonal Forest and possibly in the Deciduous Seasonal Forest (Rossi, 2000; Rossi et al., 2010).

Duarte (1998), based on significant morphological and karyotypic differences, reconsidered the existence of $M$. rondoni as a separate species from $M$. gouazoubira, as originally was proposed by Miranda-Ribeiro (1919). Later, Rossi (2000) performed a taxonomic revision based on morphological analysis of specimens from seven 


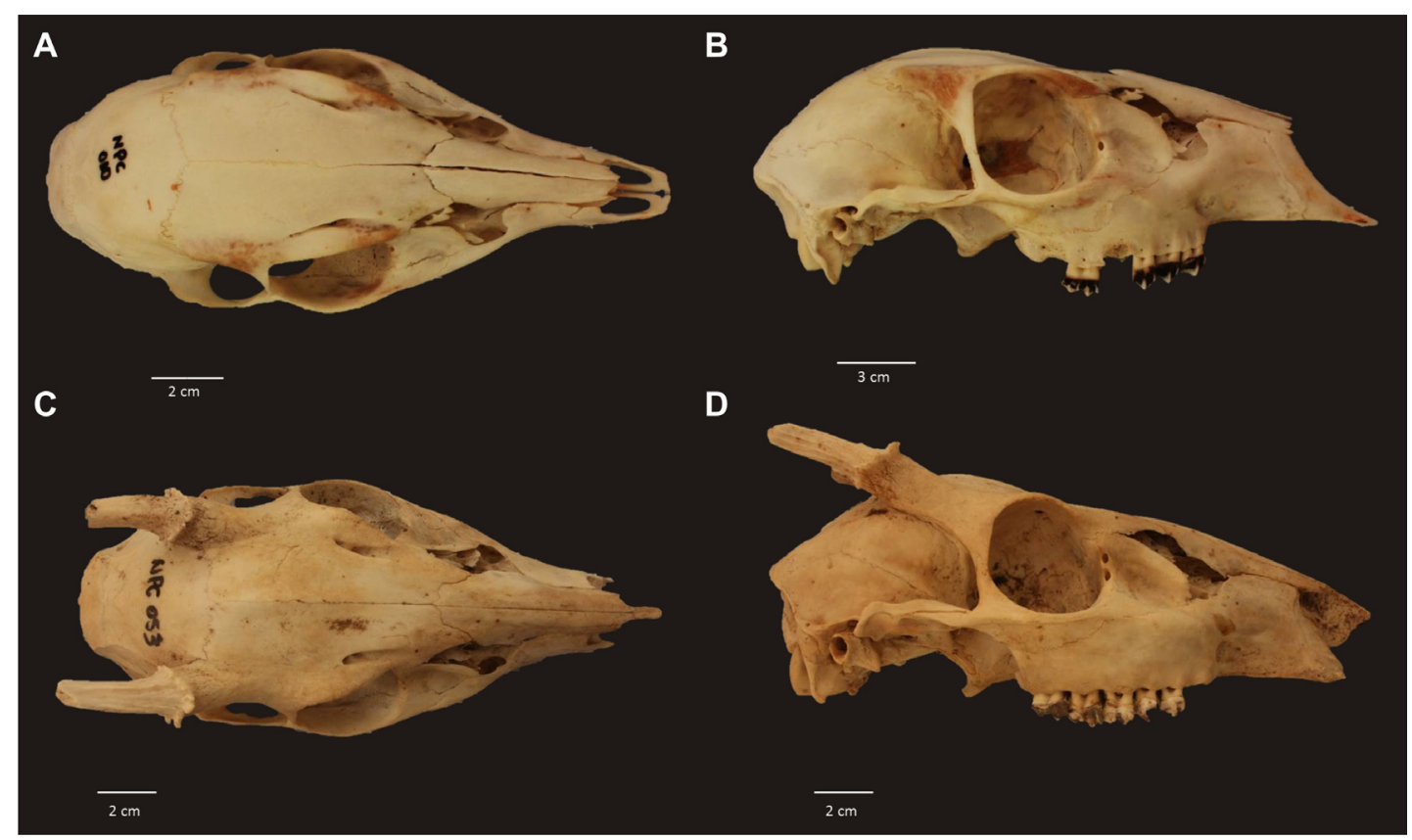

Fig. 2. Skull of an adult female (NPC 010) and adult male (NPC053) of Mazama nemorivaga. A) Dorsal view of adult female, B) Lateral view of adult female, C) Dorsal view of adult male, D) Lateral view of adult male.

northern Brazilian states and considered that the species $M$. rondoni is a synonym of $M$. nemorivaga. Currently, $M$. nemorivaga is recognized as a valid species, occupying the Amazonian region (Duarte et al., 2008; Duarte et al., 2010; Duarte \& González, 2010; Fiorillo et al., 2013; Rossi \& Duarte, 2016).

\section{Comparative craniometrical study}

Previous craniometrical studies on South American deer were reported by Wemmer \& Wilson (1987), and Merino et al. (2005), which analysed interspecific variation and phylogenetic relationship. Skull morphometry can be a useful tool for analysing intraspecific variation as has been reported by Cabrera (1943), González et al . (2002), and Rossi (2000) from several Brazilian Mazama species. The craniometric study of Rossi (2000), that included an extensive sampling of brocket deer species failed to distinguish two different species of red brockets deer (M. americana and $M$. bororo) but discriminated by canonical analysis the two gray brockets (M. gouazoubira and $M$ nemorivaga). As a part of an integrative project, Carranza et al. (2017) found evidence revealing weak premating behaviour isolation between $M$. gouazoubira and $M$ nemorivaga, being more common at intraspecific interactions and suggesting discrimination between species.
Cursino \& Duarte (2017) identified significant differences on the morphology of the spermatozoa and the ejaculate of both species. One of the characteristics that most clearly differentiated between them was the colour of the ejaculate (white for $M$. gouazoubira and reddish for $M$. nemorivaga), and sperm head dimensions.

Our aim was to carry out a comparative craniometric study between $M$. gouazoubira y $M$. nemorivaga, based mostly on specimens deposited in Brazilian museum's collections, in order to analyse the intra and interspecific variation between these two cryptic species. Our purpose was to determine if there are differential cranial characteristics between these two taxa, to initiate a morphological database that allows examining in more detail the dynamics of the geographic and genetic variation to determine priority conservation units.

\section{MATERIAL AND METHODS}

\section{Collections analysed and measurements performed}

We reviewed the mammal collections of the following Brazilian museums: National Museum of Rio de Janeiro (MNRJ), Museum of Zoology of the University of São Paulo (MZUSP), Museum of Biology Professor Mello Leitão (MBML), 


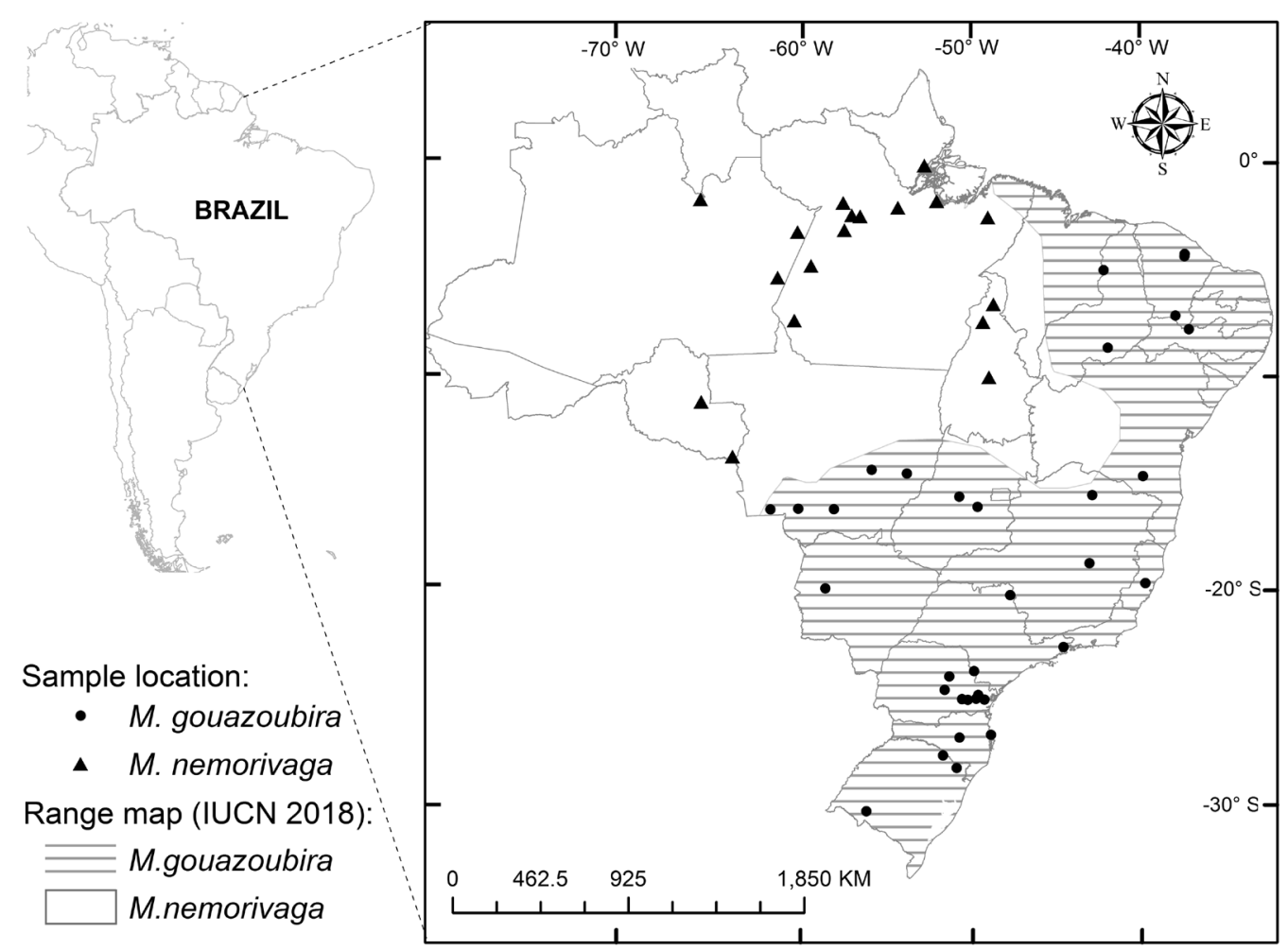

Fig. 3. Individuals measured and mapped with ArcGIS 10.1 according with the information recorded on the museum collections detailed in Appendix II.

Museum of Zoology of the Pontifical Catholic University of Rio Grande do Sul (PUC-RS), Museum of Zoology of the Federal University of Pernambuco (UFPE), Emilio Goeldi Museum Paraense (MuseoGoeldi), Museum of Natural History Capão da Imbuia (MHNCI), Museum of Zoology of the Federal University of Paraíba (UFPB) and Museum of the Deer Research and Conservation Center of UNESP (NUPECCE). The specimens we included in this study were originally nominated as: Mazama gouazoubira, $M$ simplicicornis, $M$. rondoni, $M$ nemorivaga, and Mazama sp.

We measured 106 skulls, but we only included in the comparative analyses 87 , because they were adults and almost complete specimens of $M$. gouazoubira (Mg: 32 females and 27 males) and $M$. nemorivaga ( $M n$ : 14 females and 14 males). Individual specimens were classified mostly based on its geographical origin and overall morphology, following Miranda Ribeiro (1919).

We took 36 measurements using digital caliper (precision $0.05 \mathrm{~mm}$ ) following the criteria of the standard measurements for cervids of Von den Driesch (1976; see Appendix I). We also con- sidered the data about age, sex and geographical location. (Appendix II). We plotted coordinates on a map using ArcGIS 10.1 (ESRI 2011) based on geographical information from each specimen label (Fig. 3).

\section{Statistical analysis}

We analysed the morphological variation of the sample, considering separately the effects of sexual dimorphism and taxonomic information. We classified the sample by sex and species, obtaining the averages, standard deviation and the variance of each variable. First, we conducted a Cluster analysis using the linkage model and Euclidean distances. To avoid the effect of sexual dimorphism, we analysed adult males and females separately.

We performed a factorial analysis in order to have an overview of the variation to simplify and reduce the 36 variables in 5 Factors. The factors were extracted using the method of the principal components (correlation matrix). Main components were log-transformed and rotated with the standard VARIMAX method. The projection of the individuals on the most informative fac- 


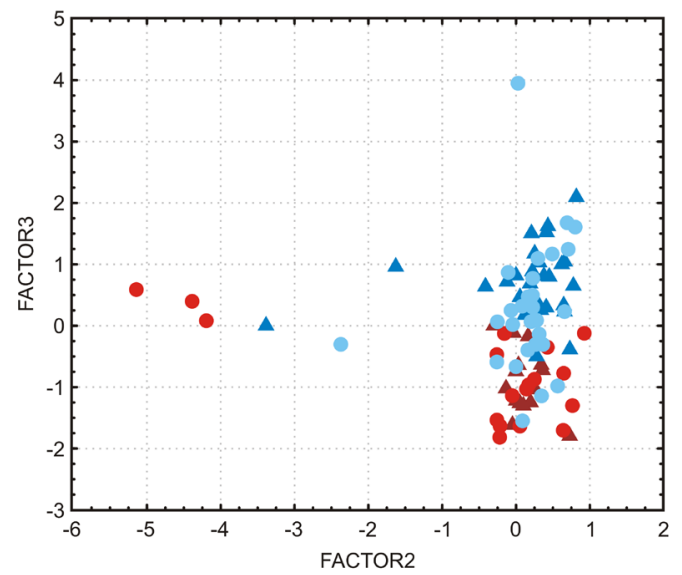

Fig. 4. Categorized two dimensions scatterplot of Factor 2 and 3 between sexes (circles -females; triangles - males) and species $M$. gouazoubira (blue) and $M$. nemorivaga (red).

tors was conducted by graphic means to detect the possible groups of specimens belonging to the same species and sex.

Analysis of variance (ANOVA) was used to test whether the factors presented statistically significant differences in relation to the sex and species (Sokal \& Rohlf, 1969). The 36 original variables were also analysed using 2-way ANOVA. The advantage of the ANOVA is that this technique allows us to test if there are significant differences between groups and classified according to a specific criterion (e.g., species) after eliminating variation that could be attributed to other classification criteria (e.g., sex). The employed software to carry out all analyses was Statistica (StatSoft 1995).

We performed a stepwise discriminant function to analyse the patterns of differentiation and to classify individuals by sex and species (Sneath \& Sokal, 1973; Sokal \& Rohlf, 1969). Using the Statistica software, we build a step wise step-by-step model of discrimination to review and evaluate all variables that contribute most to the discrimination between sexes and species (using the same probability model for each class of classification). Next, that variable will then be included in the model, and Statistica software will proceed to the next step.

\section{RESULTS AND DISCUSSION}

Our results showed that gray brocket deer $(M$. gouazoubira) exhibited a wider intraspecific variation than the Amazonian brown brocket deer $(M$. nemorivaga). The averages of 36 measures are

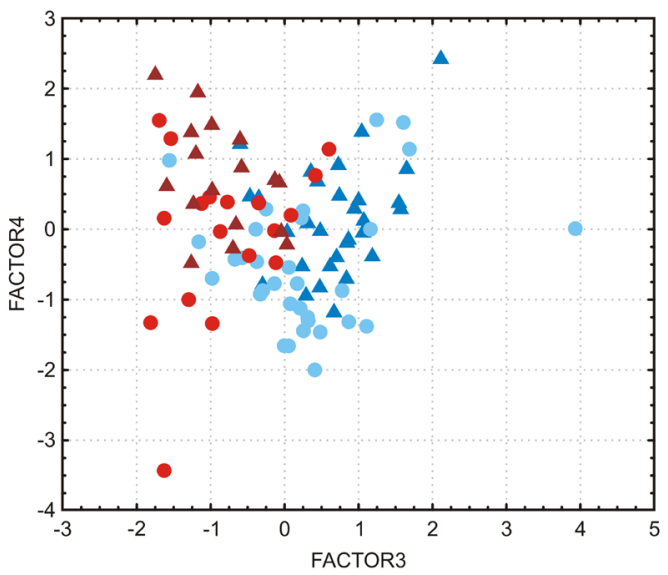

Fig. 5. Categorized two dimensions scatterplot of Factor 3 and 4 between sexes (circles -females; triangles - males) and species $M$. gouazoubira (blue) and $M$. nemorivaga (red).

summarized in Appendix III, discriminated by sex and species. A wide intraspecific variability is observed as shown by the wide range of standard deviation of most measurements. In addition, most specimens belonging to $M$. gouazoubira were larger in most of the variables, being approximately $5 \%$ larger in both sexes. The exceptions were 3 measures: premolar-prosthion (PREPO), basifacial axis (BACR), and least breadth between the orbits (LBBO), which were larger in $M$. nemorivaga in both sexes. These results are indicative of differences in the skull shape between $M$. gouazoubira and $M$. nemorivaga.

When we analysed the behaviour of the variables using the Euclidean distance for performing a cluster analysis, we observed a diffuse morphometric differentiation pattern. To avoid the effect of sexual dimorphism, we considered separately the samples of adult males and females, retrieving not clear cluster aggrupation in any case. This would be explained by the wide intraspecific variability, also seen in standard deviation values (Appendix III). Alternatively, this situation would be a reflect of the large intra and interspecific variability of both species, that also have been evidenced by cytogenetic and molecular data (Duarte et al., 2008; González et al., 2010; Fiorillo et al., 2013).

Because cluster analysis was not efficient to discriminate between the two taxa, we proceed to perform a Factorial Analysis, that allows us to simplify and summarize the 36 morphometric variables. As a result, we reduced them to 5 factors that account for $70 \%$ of the total variance of cranial measurements (Table 1). When individuals were discriminated by sex, we observed that 
TABLE 1. Factors extracted from 36 cranial variables, using the principal components method and rotated to normalize them with the procedure VARIMAX (see Appendix I by the abbreviation of the variable names). The values correspond to the correlation coefficients between the variables and each factor. The red colour indicates if the variables that have a strong association $(|r|>0.7)$ with the factor.

\begin{tabular}{|c|c|c|c|c|c|}
\hline Variable & Factor1 & Factor2 & Factor3 & Factor4 & Factor5 \\
\hline LT & 0.286452 & 0.869569 & 0.158049 & 0.19495 & 0.100732 \\
\hline CBL & 0.843446 & 0.213922 & 0.034452 & 0.03433 & 0.267019 \\
\hline BL & 0.929059 & 0.14319 & 0.039895 & 0.10070 & -0.08427 \\
\hline SSL & 0.799663 & 0.231384 & 0.080415 & -0.21113 & -0.04072 \\
\hline PREPRO & 0.447127 & 0.052701 & -0.06201 & 0.788386 & -0.03294 \\
\hline BACR & 0.637126 & 0.29884 & 0.081293 & -0.60701 & -0.02521 \\
\hline BAF & 0.748514 & 0.126449 & 0.024389 & 0.472774 & -0.34856 \\
\hline NP & 0.034558 & 0.255017 & 0.874958 & 0.069166 & 0.042763 \\
\hline MFL & 0.026437 & -0.04948 & 0.801034 & 0.181996 & 0.041879 \\
\hline $\mathbf{L N}$ & 0.012774 & -0.06431 & 0.791171 & 0.190894 & 0.026254 \\
\hline LR & 0.021269 & 0.132543 & 0.890747 & -0.09592 & 0.046451 \\
\hline LP & 0.237055 & 0.864208 & 0.155263 & 0.240091 & 0.071909 \\
\hline ACI & 0.278002 & 0.885506 & 0.159525 & -0.0957 & 0.095929 \\
\hline GLN & 0.021322 & 0.255239 & 0.813955 & -0.04509 & 0.158116 \\
\hline MPL & 0.802382 & 0.267948 & 0.070548 & 0.220883 & -0.37204 \\
\hline OPL & 0.715829 & 0.483821 & 0.056856 & 0.145906 & 0.001632 \\
\hline LLPRMAX & 0.117075 & 0.785392 & 0.278175 & 0.06666 & 0.042813 \\
\hline LCHEE & 0.129735 & 0.839277 & -0.05462 & -0.18198 & -0.01392 \\
\hline LMR & 0.148759 & 0.789334 & -0.05142 & -0.06263 & -0.03669 \\
\hline LPREM & 0.063803 & 0.684516 & -0.07619 & -0.34069 & -0.01773 \\
\hline GLOR & 0.245308 & 0.640309 & 0.040834 & 0.40201 & 0.271366 \\
\hline GHOR & 0.166043 & 0.440228 & -0.0316 & 0.66737 & 0.136402 \\
\hline GMBOO & 0.15532 & 0.679786 & 0.145244 & -0.00062 & 0.299191 \\
\hline GBOC & 0.842432 & 0.160279 & 0.016849 & -0.03322 & 0.351458 \\
\hline GBPP & 0.589425 & 0.042624 & 0.000396 & 0.133384 & 0.351738 \\
\hline GBFM & 0.839179 & 0.093547 & -0.0348 & -0.04943 & 0.340387 \\
\hline HFM & 0.861991 & 0.024611 & -0.05458 & 0.18868 & 0.025944 \\
\hline GBBC & 0.221579 & 0.704721 & 0.138746 & 0.17584 & 0.395395 \\
\hline LFBO & 0.130315 & 0.592853 & 0.142707 & 0.04564 & 0.641238 \\
\hline GBAO & 0.553046 & 0.458219 & 0.116566 & -0.36543 & 0.151055 \\
\hline LBBO & 0.041791 & -0.11419 & 0.413937 & 0.713914 & 0.065617 \\
\hline ZYB & 0.396123 & 0.111534 & -0.03281 & 0.0279 & -0.07624 \\
\hline GBN & -0.02863 & 0.189974 & 0.754229 & -0.15539 & 0.04816 \\
\hline GBPM & 0.063795 & 0.404043 & 0.204053 & 0.064715 & -0.12393 \\
\hline BNUCR & 0.81744 & 0.188693 & 0.053509 & 0.164946 & -0.29628 \\
\hline CBURR & -0.07058 & 0.158828 & 0.20948 & 0.061462 & 0.688217 \\
\hline Expl.Var & 8.636511 & 7.834542 & 4.592067 & 3.087693 & 2.126423 \\
\hline Prp.Totl & 0.239903 & 0.217626 & 0.127557 & 0.085769 & 0.059067 \\
\hline
\end{tabular}


sexual dimorphism exists in most of the variables (Fig. 4 and 5), as often occurred in other cervid species, including Neotropical ones, such as the pampas deer (Ozotoceros bezoarticus; González et al., 2002). The factor 1 was associated with 10 variables; while five represent the skull length, the other five were related to the width in the posterior part of the cranium. However, it should be noted that the skull length (factor 1) did not differ significantly between sexes and species. We found that values for females of $M$. gouazoubira, associated to this factor, were greater than those of the males. The factor 2 was also associated with seven variables (Table I detailed), being three of them related to cranial length and to the length of the dental series. These variables discriminated significantly among species (Fig. 4). As this factor was associated with the dental series measures would be indicating that the two species were adapted to different types of forest habitats and food, as had already been emphasized by Duarte (1998) and Rossi (2000). In contrast, factor 3 was correlated with four of the measures that define the length of the face (Table 1). The factor 4 was associated with the unique three measures that were larger in the $M$. nemorivaga specimens (i.e., PREPRO, BACR and LBBO). In addition, it was the only one with highly significant differences between both sexes and species (Fig. 5). Finally, factor 5 grouped the variables that exhibited low correlation than $70 \%$ and only discriminated between sexes.

In order to investigate whether the observed differentiation was statistically significant, we performed an ANOVA using the 36 original variables and the five factors obtained by grouping individuals according to sex and species (Table 2 and 3). Significant differences were observed in the two data sets (Table 2 and 3). Of the 36 variables analysed, 15 did not show significant differences between species and sexes. The 21 variables that discriminated between the two species and that exhibited high significant $F$ values $(p<0.05)$ were those related to the length of the skull and the shape of the face. The ANOVA performed with the five extracted factors also showed highly significant values in 3 of them (Table 3 ). The variables associated with factors 1 and 3 did not show significant differences. Factors 2, 4 and 5 showed statistically significant differences (Table 3 ), being a clear indicator that the individuals come from two morphometrically different species.

Subsequently, we performed a discriminant function analysis using 36 skull variables under a step wise forward model to classify the sample according to sex and species. When the en-
Table 2. Analysis of Variance of 36 skull measurements between two gray brocketspecies. For abbreviations see the Appendix I.

\begin{tabular}{lrr}
\hline Measurements & \multicolumn{1}{c}{$\boldsymbol{F}$} & \multicolumn{1}{c}{$\boldsymbol{p}$-value } \\
\hline LT & 3.997955 & 0.010356571 \\
CBL & 0.389642 & 0.760756033 \\
BL & 0.111723 & 0.953024329 \\
SSL & 2.922577 & 0.038700564 \\
PREPRO & 6.999574 & 0.000296478 \\
BACR & 6.399308 & 0.00059265 \\
BAF & 1.155264 & 0.331865568 \\
NP & 2.954273 & 0.037219479 \\
MFL & 0.693537 & 0.558565874 \\
LN & 0.494338 & 0.687190641 \\
LR & 3.873566 & 0.012094617 \\
LP & 2.818688 & 0.043982157 \\
ACI & 10.0679 & $9.96367 \mathrm{E}-06$ \\
GLN & 4.441925 & 0.006070011 \\
MPL & 0.838965 & 0.476319655 \\
OPL & 0.499605 & 0.683578609 \\
LLPRMAX & 4.80377 & 0.00390652 \\
LCHEE & 10.72769 & $4.95719 \mathrm{E}-06$ \\
LMR & 6.447795 & 0.000560207 \\
LPREM & 1.545 .552 & \\
GLOR & 9.373405 & $2.10226 \mathrm{E}-05$ \\
GHOR & 1.903393 & 0.135371717 \\
GMBOO & 2.753001 & 0.047688236 \\
GBOC & 11.76916 & $1.68302 \mathrm{E}-06$ \\
GBPP & 0.584657 & 0.626738197 \\
GBFM & 0.233286 & 0.872945328 \\
HFM & 0.770587 & 0.513712235 \\
GBBC & 1.083439 & 0.360748985 \\
LFBO & 5.510416 & 0.001681441 \\
GBAO & 12.9956 & $4.87454 \mathrm{E}-07$ \\
LBBO & 4.562587 & 0.005222755 \\
GBB & 0.220902454 \\
\hline
\end{tabular}


Table 3. Factorial ANOVA. References: $F$ values 2 degree of freedom and Significant effects $p<0.05$

\begin{tabular}{lrr}
\hline FACTOR & \multicolumn{1}{c}{$\boldsymbol{F}$} & \multicolumn{1}{c}{$\boldsymbol{p}$-value } \\
\hline FACTOR1 & 0.25358 & 0.858575 \\
FACTOR2 & 7.90992 & 0.000107 \\
FACTOR3 & 1.71676 & 0.169963 \\
FACTOR4 & 11.89908 & 0.000002 \\
FACTOR5 & 18.18664 & 0 \\
\hline
\end{tabular}

Table 4. Classification Matrix (Rows: Observed Classification, Columns: Expected Classification)

\begin{tabular}{lccc}
\hline $\begin{array}{l}\text { Classifi- } \\
\text { cation } \\
\text { gender }\end{array}$ & $\begin{array}{c}\text { Correct } \\
\text { Percen- } \\
\text { tage }\end{array}$ & $\begin{array}{c}\text { Female } \\
\boldsymbol{p}=\mathbf{0 . 5 0}\end{array}$ & $\begin{array}{c}\text { Male } \\
\boldsymbol{p}=\mathbf{0 . 5 0}\end{array}$ \\
\hline Female & 100 & 45 & 0 \\
Male & 92.68 & 3 & 38 \\
Total & 96.51 & 48 & 38 \\
\hline
\end{tabular}

Table 5. Classification Matrix (Rows: Observed Classification; Columns: Expected Classification)

\begin{tabular}{|c|c|c|c|}
\hline & $\begin{array}{c}\text { Correct } \\
\text { Percentage }\end{array}$ & $\begin{array}{c}\text { M. gouazou- } \\
\text { bira } \\
p=0.50\end{array}$ & $\begin{array}{c}\text { M. nemori- } \\
\text { vaga } \\
p=0.50\end{array}$ \\
\hline $\begin{array}{l}\text { M. goua- } \\
\text { zoubira }\end{array}$ & 100 & 59 & 0 \\
\hline $\begin{array}{l}\text { M. nemori- } \\
\text { vaga }\end{array}$ & 100 & 0 & 27 \\
\hline Total & 100 & 59 & 27 \\
\hline
\end{tabular}

tire sample was considered, the gender discrimination found was significant $(F=10.86, p<$ 0.0001 ), confirming that there is a sexual sharp dimorphism in both species (Table 4). When we considered the whole sample (not separated by sex), we found significant differences between the 2 species $(F=6.9201, p<0.0001)$, with all the individuals correctly classified (Table 5 ). Our results were also corroborated in a limited sample of gray brockets, that was further analysed using others evidences, such as cytogenetics and biometrics (Rossi, 2000).

Duarte et al. (2008) analysed a sample of Amazonian brown brocket deer using molecular markers and suggested the existence of two genetically differentiated groups: one would be occurring in the western region of Amazonia and the other in the east. However, it is necessary to increase the sample size to confirm this hypothesis and to evaluate if this genetic difference is also correlated with some kind of craniometric differentiation.

\section{CONCLUSIONS}

This study supports previous findings reported by Miranda Ribeiro (1919) and Rossi (2000) that there are two craniometrically distinct species of gray brockets in Brazil: M. gouazoubira and $M$. nemorivaga. However, a more detailed analysis of geographical patterns of morphological differentiation need to be conducted in the future, using a larger sample than those presented here. It would be important to extend the sampling to collections outside Brazil for further examination of the morphological variation and taxonomy within gray brocket deer species, in order to determine priority conservation units among them.

\section{ACKNOWLEDGMENTS}

We acknowledge to Guillermo Cassini and Pablo Teta for inviting us to participate of this special volume to honour Dr. José Yepes (18971976), a prominent Argentinean mammologist that highlight the importance of considering the geographical distribution for interpretations of modern systematics (García, 2018). Also, to two anonymous reviewers who performed valuable editorial comments that greatly improve this manuscript. We are grateful to the following agencies that funded our research: Fundação de Amparo à Pesquisa do Estado de São Paulo (FAPESP), Conselho Nacional de Desenvolvimento Científico e Tecnológico (CNPq), Comision Sectorial de Investigación Cientifica de Universidad de la República (CSIC-UDELAR), Programa de Desarrollo de Ciencias Básicas (PEDECIBA), Agencia Nacional de Investigación e Innovación (ANII), and Lóreal-Unesco from Uruguay. We also want to thank to all curators for authorized to museum Mastozoological collections: Museum of Rio de Janeiro (MNRJ), Museum of Zoology of the University of São Paulo (MZUSP), Museum of Biology Professor Mello Leitão (MBML), Museum of Zoology of the Pontifical Catholic University of Rio Grande do Sul (PUC-RS), Museum of Zoology of the Federal University of Pernambuco (UFPE), Emilio Goeldi Museum Paraense, Museum of Natural History Capão da Imbuia (MHNCI), Museum of Zoology of the Federal University of Paraíba (UFPB) and Museum of the Deer Research and Conservation Center of UNESP (NUPECCE). 


\section{REFERENCES}

Allen, J.A. 1915. Notes on American deer of the genus Mazama. Bull. Am. Mus. Nat. Hist., 34: 521-553.

Ávila-Pires, F.D. 1959. As formas sul-americanas do veado-virá. An. Acad. Brasileira Ciências 31(4): 547-556.

Bergallo, H.G.; Rocha, C.F.D.; Alves, M.L.S. \& Sluys, M. 2000. A fauna ameaçada de extinção do Estado do Rio de Janeiro. EdUERJ, Rio de Janeiro, Brazil 166pp.

Black-Decima, P.; Rossi, R.V.; Vogliotti, A.; Cartes, J.L.; Maffei, L.; Duarte, J.M.B.; González, S. \& Juliá, J.P. 2010. Brown Brocket Deer Mazama gouazoubira (Fischer 1814). In: Duarte, J.M.B. \& González, S. (Eds.) Neotropical Cervidology, Biology and Medicine of Latin American Deer.Funep/IUCN, Jaboticabal/Gland, pp. 190-201.

Black-Decima, P.A. \& Vogliotti, A. 2016. Mazama gouazoubira. The IUCN Red List of Threatened Species 2016: e.T29620A22154584. http:// dx.doi.org/10.2305/IUCN.UK.2016-2.RLTS. T29620A22154584.en. Downloaded on 18 October 2017.

Brooke, V. 1878. On the classification of the Cervidae, with a synopsis of the existing species. Proceedings of the Zoological Society of London, 1878: 883-928.

Cabrera, A. 1943. Sobre la sistemática del venado y su variación individual y geográfica. Revista del Museo de la Plata (NS), Tomo III, Zool, 18, 5-41.

Cabrera, A. 1960. Catálogo de los mamíferos de América del Sur. Revista Museo Argentino Bernardino Rivadavia, 4:309-732.

Cabrera, A. \& Yepes, J. 1960. Mamíferos Sudamericanos: Vida, costumbres y descripción. Ediar Buenos Aires, 370 pp.

Carranza, J. Roldán, M.; Peroni, E.F.C.;\& Duarte, J.M.B. 2017. Weak premating isolation between two parapatric brocket deer species. Mammalian Biology, 87: 17-26.

Cursino, M. S. \& Duarte, J. M. B. 2016 Using sperm morphometry and multivariate analysis to differentiate species of gray Mazama. R. Soc. open sci. 3: 160345. http://dx.doi.org/10.1098/rsos.160345

Cuvier, G.F. 1817. Dictionnaire des Sciences Naturales. Zoologie. Mammiferes. Paris, F. G. Levrault, 7:1534.

Czernay, S. 1987. Spiesshirsche und Pudus.Die Neue Brehm Bucherei. 581:1-84.

Duarte, J. M. B. 1992. Aspectos taxonômicos e citogenéticos de algumas espécies de cervídeos brasileiros. Jaboticabal: Faculdade de Ciências Agrárias e Veterinárias. Dissertação de Mestrado 153pp.

Duarte, J.M.B. 1996. Guia de identificação de Cervídeos brasileiros. FUNEP, Jaboticabal. 14 pp.

Duarte, J.M.B. 1998. Análise citogenética e taxonômica do gênero Mazama (Cervidae; Artiodactyla) no Brasil. Não paginado. Tese (Doutorado em Ciências Biológicas) - Instituto de Biociências, Universidade Estadual Paulista, Botucatu.

Duarte, J.M.B. \& González, S. 2010. Neotropical Cervidology, Biology and Medicine of Latin
American Deer:Funep/IUCN, Jaboticabal/Gland, $393 \mathrm{pp}$.

Duarte, J.M.B.; González, S. \& Maldonado, J.E. 2008. The surprising evolutionary history of South American deer. Molecular Phylogenetics and Evolution, 49:17-22.

ESRI. 2011. ArcGIS Desktop: release 10. Environmental Systems Research Institute, Redlands, California.

Fiorillo, B.F.; Sarria-Perea, J.A.; Abril, V.V. \& Duarte, J.M.B. 2013. Cytogenetic description of the Amazonian brown brocket Mazama nemorivaga (Artiodactyla, Cervidae). Comparative Cytogenetics 7(1): 25-31.

García, S. 2018. La trayectoria del zoólogo José Yepes: colecciones, viajes y zoogeografía en las décadas de 1930 y 1940. Revista del Museo Argentino de Ciencias Naturales, Nueva Serie 20: 71-81. Doi: 10.22179/REVMACN.20.579

González, S., Álvarez, F. \& Maldonado, J. E. 2002. Morphometric differentiation of the endangered Pampas deer (Ozotoceros bezoarticus L. 1758) with description of new subspecies from Uruguay. Journal of Mammalogy, 83: 1127-1140.

González, S.; Duarte, J.M.B. \& Maldonado, J.E. 2010. Molecular Phylogenetics and Evolution. In: Duarte, J.M.B. \& González, S. (Eds.) Neotropical Cervidology, Biology and Medicine of Latin American Deer.Funep/IUCN, Jaboticabal/Gland, pp. 12-17.

González, S. \& Elizondo, C. 2010. Distribución de Mazama gouazoubira en el Uruguay. Primer Congreso Uruguayo de Zoología, 5 al 10 Diciembre, Montevideo-Uruguay.

Leeuwenberg, F.; Oliveira-Cabral, I. \& Lara-Resende, S. 1999. Gray brocket deer (Mazama gouazoubira) in the brazilian savanne. Deer Specialist Group News 15:14-14.

Lydekker, R. 1898. The deer of all lands. Rowland Ward, London $408 \mathrm{pp}$.

Miranda Ribeiro A. de 1919. Os veados do Brazil secundo as colleccoes Rondon e de varios museus nacionaes e estrangeiros. Revista do Museu Paulista XI, 209 317, Láms. I XXV, Sao Paulo.

Merino M. L., Milne N. and Vizcaíno S. F. 2005. A cranial morphometric study of deer (Mammalia, Cervidae) from Argentina using three-dimensional landmarks. Acta Theriologica 50: 91-108.

Merino, M.L. \& Rossi, R.V. 2010. Origin, Systematics, and Morphological Radiation. In: Duarte, J.M.B. \& González, S. (Eds.) Neotropical Cervidology, Biology and Medicine of Latin American Deer. Funep/IUCN, Jaboticabal/Gland, pp. 2-11.

Pinder, L. \& Leeuwenberg, F. 1997. Veado-catingueiro (Mazama gouazoubira, Fischer 1814). In: Duarte, J.M.B. (Ed). Biologia e conservação de cervídeos sul-americanos: Blastocerus, Ozotoceros e Mazama. FUNEP, Jaboticabal, pp. 60-68.

Rafinesque, C. S. 1817. New species of Mammifers, noticed in the notes to the (Tableau methodique des Mammiferes) Methodical Picture of the Mammifers, by D. Desmarets [sic], in the $24^{\text {th }}$ and last volume of the French New Dictionary of Natural History. 
Paris, 1804. Translated and improved, by C. S. Rafinesque. The American Monthly Magazine and Critical Review 1:361-363.

Rodrigues, T.F.; Cerveira, J. \& Duarte, J.M.B. 2014. Uso de áreas agrícolas por Mazama gouazoubira (Mammalia, Cervidae) no Estado de São Paulo. Iheringia, Série Zoologia 104 (4):439-445.

Rodrigues, T.F.; Kays, R.; Parsons, A.; Versiani, N.F. Paolino, R.M.; Pasqualotto, N.; Krepschi, V. G. \& Chiarello, A.G. 2017. Managed forest as habitat for gray brocket deer (Mazama gouazoubira) in agricultural landscapes of southeastern Brazil. Journal of Mammalogy 98(5): 1301-1309.

Rossi, R.V. 2000. Taxonomia de Mazama Rafinesque, 1817 do Brasil (Artiodactyla, Cervidae). M.S. thesis, Universidade de São Paulo, São Paulo 174 pp.

Rossi, R.V. and Duarte, J.M.B. 2016. Mazama nemorivaga. The IUCN Red List of Threatened Species 2016http://dx.doi.org/10.2305/IUCN.UK.2016-1. RLTS.T136708A22158407.en. Downloaded on 18 October 2017.

Rossi, R.V.; Bodmer, R.; Duarte, J.M.B.; Trovati, R.G. 2010. Amazonian Brown Brocket Deer Mazama nemorivaga (Cuvier 1817).In: Duarte, J.M.B.
\& González, S. (Eds.) Neotropical Cervidology, Biology and Medicine of Latin American Deer. Funep/IUCN, Jaboticabal/Gland, pp. 202-210.

StatSoft. 1995. Statistica $5.1 \mathrm{~h}$ for Windows. StatSoft. Tulsa, Oklahoma.

Sneath, P.H.R.A. \& Sokal, R.R. 1973. Numerical taxonomy: the principles and practice of numerical classification. 2nd edn, W. H. Freeman and Co, 549 pp.

Sokal, R. R. and J.F. J. Rohlf. 1969. Biometry. W. H. Freeman and Co.. San Francisco, California, 776 pp.

von den Driesch, A. 1976. A guide to the measurement of animal bones from archaelogical sites, as developed by the Institut für Palaeoanatomie, Domestikations forschung und Geschichte der Tiermedizin of the University of Munich. Peabody Museum Bulletin, Harvard University, Cambridge, Massachusetts 1:35-37.

Wemmer C. and Wilson D. 1987. Cervid brain size and natural history. In: C. M. Wennner, (Ed.) Biology and management of the Cervidae. Smithsonian Institution Press, Washington pp, 189-199.

Doi: 10.22179/REVMACN.20.561

Recibido: 2-XI-2017

Aceptado: 10-V-2018

APPENDIX I. List detailed of the cranial measurements taken and their abbreviation according to the criteria explicated by Von den Driesch (1976):

1) Total Length LT,

2) Condylobasal length CBL

3) Basal length BL

4) Short S Length SSL

5) Premolar Prosthion PREPRO

6) Basicranial axis BACR

7) Basifacial axis BAF

8) Nasion-Prosthion NP

9) Median Frontal Length MFL

10) Lambda Nasion LN

11) Lambda Rhinion LR

12) LamdaProsthion LP

13) Acrocranian-infraorbitale ACI

14) Greatest Length of nasal GLN

15) Median palatal length MPL

16) Oral palatal length OPL

17) Lateral length of the premaxilla LLPRMAX

18) Lenght of cheektooth LCHEE

19) Lenght of molar row LMR

20) Length of premolar row LPREM
21)Greatest length of the orbit GLOR

22) Greatest height of the orbit GHOR

23) Greatest mastoid breadth Otion-Otion GMBOO

24) Greatest breadth occipital condyles GBOC

25) Greatest breadth of paraoccipital process GBPP

26) Greatest breadth of foramen magnum GBFM

27) Height of foramen magnum HFM

28) Greatest breadth of the braincase GBBC

29) Least frontal breadth in the orbits LFBO

30) Greatest breadth across the orbits GBAO

31) Least breadth between the orbits LBBO

32) Zygomatic Breadth ZYB

33) Greatest breadth across the nasals GBN

34) Greatest breadth across premaxillae GBPM

35) Basion the highest point of the superior nuchal crest BNUCR

36) Circunference of the burr CBURR 
APPENDIX II. List of revised specimens.Acronyms are as follow: Museum of Rio de Janeiro (MNRJ), Museum of Zoology of the University of São Paulo (MZUSP), Museum of Biology Professor Mello Leitão (MBML), Museum of Zoology of the Pontifical Catholic University of Rio Grande do Sul (PUCRS), Museum of Zoology of the Federal University of Pernambuco (UFPE), Emilio Goeldi Museum Paraense (MuseoGoeldi), Museum of Natural History Capão da Imbuia (MHNCI), Museum of Zoology of the Federal University of Paraíba (UFPB), Zoobotanica Foundation of Rio Grande do Sul (FZB), and Museum of the Deer Research and Conservation Center of UNESP (NUPECCE).

\begin{tabular}{|c|c|c|c|c|c|}
\hline & ID & SEX & SPECIES & MUSEUM & ORIGIN \\
\hline 1 & 3893 & female & M.g & FZB & Foz do Juabifi, Esmeralda - RS \\
\hline 2 & 15750 & male & M.g & PUCRS & Bom Jesus-RS \\
\hline 3 & 1822 & male & M.g & PUCRS & BR290, Serra do Caverá, Alegrete - RS \\
\hline 4 & 91 & female & M.g & MHNCI & BR277, km 20, Morretes - PR \\
\hline 5 & 4085 & male & M.g & MHNCI & Capivari, Campina Grande do Sul - PR \\
\hline 6 & 4101 & female & M.g & MHNCI & $\begin{array}{l}\text { Klabin Reflorestadora (Próximo Lagoa Telêmaco } \\
\text { Borba) - PR }\end{array}$ \\
\hline 7 & 519 & male & M.g & MHNCI & Fazenda Santa Rita, Palmeira - PR \\
\hline 8 & 4079 & male & M.g & MHNCI & São Luiz do Puruña - PR \\
\hline 9 & 149 & female & M.g & MHNCI & Vale do Rio Ivaí - PR \\
\hline 10 & 148 & female & M.g & MHNCI & Vale do Rio Ivaí - PR \\
\hline 11 & 154 & male & M.g & MHNCI & Chácara do Dr. Loureiro - Curitiba - PR \\
\hline 12 & 150 & male & M.g & MHNCI & Vale Porto São José - PR \\
\hline 13 & 153 & female & M.g & MHNCI & Vale Porto São José - PR \\
\hline 14 & 13559 & male & M.ne & MZUSP & Caxiricatuba, rioTapajós-PA \\
\hline 15 & 7163 & female & M.ne & MZUSP & Caxiricatuba, rioTapajós-PA \\
\hline 16 & 1153 & male & M.g & MZUSP & Itararé-SP \\
\hline 17 & 814 & female & M.g & MZUSP & Franca-SP \\
\hline 18 & 1848 & female & M.g & MBML & São Lourenço, Santa Teresa-ES \\
\hline 19 & 1823 & female & M.g & MBML & Estação Biológica de Santa Lúcia, Santa Teresa-ES \\
\hline 20 & 27 & female & M.g & MNRJ & MT \\
\hline 21 & 7 & male & M.g & MNRJ & Santa Catarina-SC \\
\hline 22 & 24 & male & M.g & MNRJ & Santa Catarina- SC \\
\hline 23 & 36355 & female & M.g & MNRJ & GO \\
\hline 24 & 60673 & male & M.g & MNRJ & Sítio Campo, Campos Sales, Crato-CE \\
\hline 25 & 60675 & female & M.g & MNRJ & Sítio Campo, Campos Sales, Crato-CE \\
\hline 26 & 60676 & female & M.g & MNRJ & Sítio Campo, Campos Sales, Crato-CE \\
\hline 27 & 60677 & female & M.g & MNRJ & Sítio Campo, Campos Sales, Crato-CE \\
\hline 28 & 63438 & male & M.g & MNRJ & $\begin{array}{l}\text { Caldeirão Inácio, PN Serra da Capivara, São } \\
\text { Raimundo 0nato-PI }\end{array}$ \\
\hline 29 & 71065 & female & M.g & MNRJ & RPPN Sesc Pantanal, Barão de Meleaço-MT \\
\hline 30 & 60664 & female & M.g & MNRJ & Sítio Campo, Campos Sales, Crato-CE \\
\hline 31 & 60667 & female & M.g & MNRJ & Sítio Campo, Campos Sales, Crato-CE \\
\hline 32 & 60668 & male & M.g & MNRJ & Sítio Campo, Campos Sales, Crato-CE \\
\hline 33 & 60670 & female & M.g & MNRJ & Sítio Campo, Campos Sales, Crato-CE \\
\hline 34 & 60663 & male & M.g & MNRJ & Sítio Campo, Campos Sales, Crato-CE \\
\hline 35 & 60662 & female & M.g & MNRJ & Sítio Campo, Campos Sales, Crato-CE \\
\hline 36 & 60661 & male & M.g & MNRJ & Sítio Campo, Campos Sales, Crato-CE \\
\hline 37 & 60656 & female & M.g & MNRJ & Cabeceira do Paranatinga-MT \\
\hline 38 & 60655 & male & M.g & MNRJ & Sítio Campo, Campos Sales, Crato-CE \\
\hline 39 & 60647 & male & M.g & MNRJ & Vitória da Conquista-BA \\
\hline 40 & 60646 & female & M.g & MNRJ & Vitória da Conquista-BA \\
\hline 41 & 60645 & male & M.g & MNRJ & Vitória da Conquista-BA \\
\hline
\end{tabular}




\begin{tabular}{|c|c|c|c|c|c|}
\hline \multicolumn{2}{|c|}{ ID } & \multirow{2}{*}{$\begin{array}{l}\text { SEX } \\
\text { female }\end{array}$} & \multirow{2}{*}{$\begin{array}{l}\text { SPECIES } \\
\text { M.g }\end{array}$} & \multirow{2}{*}{$\begin{array}{l}\text { MUSEUM } \\
\text { MNRJ }\end{array}$} & \multirow{2}{*}{$\begin{array}{l}\text { ORIGIN } \\
\text { Vitória da Conquista-BA }\end{array}$} \\
\hline 42 & 60644 & & & & \\
\hline 43 & 60643 & female & M.g & MNRJ & Vitória da Conquista-BA \\
\hline 44 & 60532 & female & M.g & MNRJ & Sítio Campo, Campo Sales-CE \\
\hline 45 & 60531 & male & M.g & MNRJ & Sítio Campo, Campo Sales-CE \\
\hline 46 & 29079 & male & M.g & MNRJ & FazendaFlorestaJanaúba-MG \\
\hline 47 & 25902 & female & M.g & MNRJ & Fazenda Três Meninas, Porto Esbiridião-MT \\
\hline 48 & 13509 & male & M.g & MNRJ & Província Conceição do Mato Dentro-MG \\
\hline 49 & 11979 & male & M.g & MNRJ & Xavantina, Rio das Mortes-MT \\
\hline 50 & 6700 & male & M.g & MNRJ & Serra da Bocaína-RJ \\
\hline 51 & 5837 & female & M.g & MNRJ & São Luís de Cáceres - MT \\
\hline 52 & 5005 & male & M.g & MNRJ & Anápolis-GO \\
\hline 53 & 60672 & male & M.g & MNRJ & Sítio Campo, Campos Sales, Crato-CE \\
\hline 54 & MR1 & male & M.ne & MNRJ & MT \\
\hline 55 & 841 & male & M.ne & MNRJ & Rio Cabixi-RO \\
\hline 56 & 1359 & female & M.ne & MNRJ & Entre os rios Jamari e Gi-Paraná-RO \\
\hline 57 & 6093 & female & M.ne & MNRJ & Lago do Batista, rio Amazonas-sul-AM \\
\hline 58 & 19200 & male & M.ne & MNRJ & Rio Guajurú, Jacurú-200km de Porto de Moz-PA \\
\hline 59 & 19201 & male & M.ne & MNRJ & Rio Guajurú, Jacurú-200km de Porto de Moz-PA \\
\hline 60 & 19202 & male & M.ne & MNRJ & Jacareacanga, rioTapajós-PA \\
\hline 61 & 60690 & male & M.ne & MNRJ & Caxiuanã-PA \\
\hline 62 & 60696 & female & M.ne & MNRJ & Rio Aracá-Mirim-PA \\
\hline 63 & 60706 & female & M.ne & MNRJ & Maués-AM \\
\hline 64 & 19207 & male & M.ne & MNRJ & Rio Guajurú, Jacurú-200km de Porto de Moz-PA \\
\hline 65 & 30470 & female & M.ne & MNRJ & Paraná do Ariaú-AM \\
\hline 66 & 60671 & female & M.ne & MNRJ & Belterra-PA \\
\hline 67 & 60679 & female & M.ne & MNRJ & Estrada Belém-Brasília (Rodobrás) km 131-TO \\
\hline 68 & 60680 & female & M.ne & MNRJ & Estrada Belém-Brasília (Rodobrás) km 131-TO \\
\hline 69 & 60682 & female & M.ne & MNRJ & Curuá, Santarém-PA \\
\hline 70 & 2391 & female & M.g & UFPE & Buriti Cortado, Timon - MA \\
\hline 71 & 2422 & male & M.g & UFPE & Buriti Cortado, Timon - MA \\
\hline 72 & 6652 & male & M.g & UFPB & São José do Belmonte-PE \\
\hline 73 & 6998 & female & M.g & UFPB & APA da Serra de Baturite, Aratuba-CE \\
\hline 74 & 6598 & male & M.g & UFPB & Mulungu-CE \\
\hline 75 & 1617 & male & M.ne & MuseoGoeldi & Manzagão-AP \\
\hline 76 & 1969 & male & M.ne & MuseoGoeldi & Rio Araguaia-TO \\
\hline 77 & 723 & male & M.ne & MuseoGoeldi & RioTocantis TO \\
\hline 78 & 1970 & male & M.ne & MuseoGoeldi & Rio Araguaia- TO \\
\hline 79 & 4393 & male & M.ne & MuseoGoeldi & Taperinha-PA \\
\hline 80 & 4409 & male & M.ne & MuseoGoeldi & Taperinha-PA \\
\hline 81 & 4393 & male & M.ne & MuseoGoeldi & Taperinha-PA \\
\hline 82 & 4395 & male & M.ne & MuseoGoeldi & Taperinha-PA \\
\hline 83 & 4404 & male & M.ne & MuseoGoeldi & \\
\hline 84 & 4392 & female & M.ne & MuseoGoeldi & Taperinha-PA \\
\hline 85 & 4406 & male & M.ne & MuseoGoeldi & Taperinha-PA \\
\hline 86 & 4394 & male & M.ne & MuseoGoeldi & Taperinha-PA \\
\hline 87 & 4399 & female & M.ne & MuseoGoeldi & Taperinha-PA \\
\hline 88 & 8066 & female & M.ne & MuseoGoeldi & Santarém-PA \\
\hline 89 & 3348 & female & M.ne & MuseoGoeldi & \\
\hline 90 & 3347 & female & M.ne & MuseoGoeldi & \\
\hline 91 & 4391 & female & M.ne & MuseoGoeldi & \\
\hline 92 & 4402 & male & M.ne & MuseoGoeldi & Taperinha-PA \\
\hline
\end{tabular}




\begin{tabular}{rrllll}
\hline \multicolumn{1}{c}{ ID } & & SEX & SPECIES & MUSEUM & ORIGIN \\
\hline 93 & 4403 & female & M.ne & MuseoGoeldi & Taperinha-PA \\
94 & 22613 & female & M.ne & MuseoGoeldi & \\
95 & NPC004 & female & M.ne & NUPECCE & Santarém-PA \\
96 & NPC005 & female & M.ne & NUPECCE & CriadouroSantarém-PA \\
97 & NPC006 & male & M.ne & NUPECCE & CriadouroSantarém-PA \\
98 & NPC010 & female & M.ne & NUPECCE & CETAS de Macapá-AP \\
99 & NPC013 & female & M.ne & NUPECCE & \\
100 & NPC017 & female & M.ne & NUPECCE & \\
101 & NPC008 & male & M.g & NUPECCE & Porto Belo-SC \\
102 & NPC009 & female & M.g & NUPECCE & Guaíra-SP \\
103 & NPC003 & female & M.g & NUPECCE & São Paulo-SP \\
104 & NPC011 & female & M.g & NUPECCE & São Paulo-SP \\
105 & NPC012 & female & M.g & NUPECCE & Maranguape-CE \\
106 & NPC014 & male & M.g & NUPECCE & Pantanal-MS \\
\hline
\end{tabular}

APPENDIX III. Summary statistics of the analysed variables discriminated by species, sex and all groups pooled together. Abbreviations: $n=$ number of specimens; $s . d .=$ standard deviation; measures are detailed in Appendix I.

\begin{tabular}{lrrrrrrrrrrrr}
\hline Variables & LT & LT & LT & CBL & CBL & CBL & BL & BL & BL & SSL & SSL & SSL \\
& Means & $n$ & s.d. & Means & $n$ & s.d. & Means & $n$ & s.d. & Means & $n$ & s.d. \\
\hline M. gouazoubira F & 179,18 & 32,00 & 15,84 & 166,50 & 32,00 & 36,03 & 153,63 & 32,00 & 31,70 & 100,63 & 32,00 & 21,46 \\
M. nemorivaga F & 169,10 & 14,00 & 13,36 & 160,48 & 14,00 & 11,30 & 148,84 & 14,00 & 11,68 & 82,60 & 14,00 & 8,45 \\
M. gouazoubira M & 183,06 & 27,00 & 11,36 & 171,10 & 27,00 & 36,03 & 149,72 & 27,00 & 44,50 & 99,93 & 27,00 & 30,00 \\
M. nemorivaga M & 174,61 & 14,00 & 5,67 & 165,76 & 14,00 & 7,19 & 152,49 & 14,00 & 6,02 & 88,86 & 14,00 & 13,18 \\
AllGroups & 178,03 & 87,00 & 13,59 & 166,84 & 87,00 & 30,00 & 151,46 & 87,00 & 31,48 & 95,62 & 87,00 & 22,92
\end{tabular}

\begin{tabular}{|c|c|c|c|c|c|c|c|c|c|c|c|c|}
\hline \multirow[t]{2}{*}{ Variables } & \multicolumn{3}{|c|}{ PREPROPREPROPREPRO } & \multirow{2}{*}{$\begin{array}{c}\text { BACR } \\
\text { Means }\end{array}$} & \multirow{2}{*}{$\begin{array}{r}\text { BACR } \\
n\end{array}$} & \multirow{2}{*}{$\begin{array}{c}\text { BACR } \\
s . d .\end{array}$} & \multirow{2}{*}{$\begin{array}{r}\text { BAF } \\
\text { Means }\end{array}$} & \multirow{2}{*}{$\begin{array}{r}\text { BAF } \\
n\end{array}$} & \multirow{2}{*}{$\begin{array}{l}\text { BAF } \\
\text { s.d. }\end{array}$} & \multirow{2}{*}{$\begin{array}{r}\text { NP } \\
\text { Means }\end{array}$} & \multirow{2}{*}{$\begin{array}{r}\mathrm{NP} \\
n \\
\end{array}$} & \multirow{2}{*}{$\begin{array}{l}\mathrm{NP} \\
\text { s.d. }\end{array}$} \\
\hline & Means & $n$ & s.d. & & & & & & & & & \\
\hline M. gouazoubira F & 53,60 & 32,00 & 8,36 & 32,76 & 32,00 & 10,30 & 122,87 & 32,00 & 13,04 & 77,71 & 32,00 & 16,91 \\
\hline M. nemorivaga $\mathbf{F}$ & 63,85 & 14,00 & 13,17 & 21,34 & 14,00 & 8,14 & 125,52 & 14,00 & 16,20 & 70,54 & 14,00 & 23,02 \\
\hline M. gouazoubira $\mathbf{M}$ & 50,42 & 27,00 & 11,77 & 33,18 & 27,00 & 11,09 & 114,70 & 27,00 & 34,56 & 84,39 & 27,00 & 7,78 \\
\hline M. nemorivaga $\mathbf{M}$ & 61,91 & 14,00 & 10,05 & 24,72 & 14,00 & 9,16 & 125,00 & 14,00 & 8,08 & 81,30 & 14,00 & 6,58 \\
\hline AllGroups & 55,60 & 87,00 & 11,67 & 29,76 & 87,00 & 10,99 & 121,11 & 87,00 & 22,17 & 79,21 & 87,00 & 15,17 \\
\hline
\end{tabular}

\begin{tabular}{|c|c|c|c|c|c|c|c|c|c|c|c|c|}
\hline Vari & MFL & MFL & MFL & $\mathrm{LN}$ & $\mathrm{LN}$ & LN & $\mathrm{LR}$ & LR & LR & LP & LP & LP \\
\hline & Means & $n$ & s.d. & Means & $n$ & s.d. & Means & $n$ & s.d. & Means & $n$ & s.d. \\
\hline M. gouazoubira F & 103,88 & 32,00 & 20,36 & 91,86 & 32,00 & 18,13 & 138,66 & 32,00 & 28,47 & 170,45 & 32,00 & 15,15 \\
\hline M. nemorivaga $\mathbf{F}$ & 103,26 & 14,00 & 6,30 & 92,09 & 14,00 & 5,15 & 115,94 & 13,00 & 52,64 & 162,05 & 14,00 & 12,73 \\
\hline M. gouazoubira $M$ & 108,12 & 27,00 & 5,73 & 95,35 & 27,00 & 5,29 & 147,00 & 27,00 & 9,83 & 173,47 & 27,00 & 10,89 \\
\hline M. nemorivaga $\mathbf{M}$ & 103,97 & 14,00 & 2,76 & 92,69 & 14,00 & 2,53 & 141,61 & 14,00 & 6,24 & 167,37 & 14,00 & 5,65 \\
\hline AllGro & 5,11 & 7,00 & 13,06 & 93,12 & 87,00 & 11,59 & 138,32 & 86,00 & 28,71 & 169,54 & 87,00 & 12,77 \\
\hline \multirow[t]{2}{*}{ Variables } & ACI & ACI & ACI & GLN & GLN & GLN & MPL & MPL & MPL & OPL & OPL & $\overline{\mathrm{OPL}}$ \\
\hline & Means & $n$ & s.d. & Means & $n$ & s.d. & Means & $n$ & s.d. & Means & $n$ & s.d. \\
\hline M. gouazoubira F & 125,39 & 2,00 & 11,07 & 44,90 & 32,00 & 13,47 & 109,71 & 32,00 & 11,37 & 73,56 & 32,00 & 9,59 \\
\hline M. nemorivaga $\mathbf{F}$ & 114,25 & 14,00 & 6,39 & 40,13 & 13,00 & 19,71 & 103,97 & 14,00 & 9,98 & 69,43 & 14,00 & 7,80 \\
\hline M. gouazoubira M & 128,93 & 27,00 & 8,07 & 53,23 & 27,00 & 7,18 & 102,07 & 27,00 & 30,72 & 72,38 & 27,00 & 16,27 \\
\hline M. nemorivaga $\mathbf{M}$ & 119,40 & 14,00 & 5,58 & 51,12 & 14,00 & 6,82 & 106,40 & 14,00 & 5,74 & 70,76 & 14,00 & 4,85 \\
\hline llGroups & 123,73 & 87,00 & 10,10 & 47,81 & 86,00 & 12,93 & 105,88 & 87,00 & 19,04 & 72,08 & 87,00 & 11,3 \\
\hline
\end{tabular}


Continuation

\begin{tabular}{|c|c|c|c|c|c|c|c|c|c|c|c|c|}
\hline Variables & $\begin{array}{l}\text { LLPR } \\
\text { MAX }\end{array}$ & $\begin{array}{l}\text { LLPR } \\
\text { MAX }\end{array}$ & $\begin{array}{l}\text { LLPR } \\
\text { MAX } 1\end{array}$ & LCHE & CHEE & HEE & LMR & LMR & LMR & LPREM & PREM & I LPREM \\
\hline & Means & $n$ & s.d. & Means & $n$ & s.d. & Means & $n$ & s.d. & Means & $n$ & s.d. \\
\hline M. gouazoubira $\mathbf{F}$ & 41,59 & 32,00 & 5,51 & 52,51 & 32,00 & 4,42 & 29,22 & 32,00 & 2,75 & 24,16 & 32,00 & $\overline{2,61}$ \\
\hline M. nemorivaga $F$ & 37,85 & 14,00 & 5,11 & 47,57 & 14,00 & 4,55 & 26,29 & 14,00 & 3,16 & 21,59 & 14,00 & 2,68 \\
\hline M. gouazoubira M & 43,21 & 27,00 & 5,12 & 53,89 & 27,00 & 3,79 & 30,04 & 27,00 & 3,36 & 24,78 & 27,00 & 2,00 \\
\hline M. nemorivaga $\mathbf{M}$ & 38,72 & 14,00 & 2,59 & 48,80 & 14,00 & 2,03 & 27,52 & 14,00 & 1,18 & 21,84 & 14,00 & 1,40 \\
\hline llGroups & 41,03 & 87,00 & 5,29 & 51,54 & 87,00 & 4,58 & 28,73 & 87,00 & 3,11 & 23,57 & 87,00 & 2,6 \\
\hline
\end{tabular}

Variables GLOR GLOR GLOR GHOR GHOR GHOR GMBOO GMBOO GMBOO GBOC GBOC GBOC $\begin{array}{llllllllll}\text { Means } & n & \text { s.d. Means } & n & \text { s.d. Means } & n & \text { s.d. Means } & n & \text { s.d. }\end{array}$

\begin{tabular}{lllllllllllll}
\hline M. gouazoubira $\mathbf{~}$ & 29,79 & 32,00 & 1,84 & 29,16 & 32,00 & 2,80 & 53,55 & 32,00 & 3,65 & 32,18 & 32,00 & 6,67 \\
M. nemorivaga $\mathbf{~ F}$ & 29,86 & 14,00 & 1,97 & 30,61 & 14,00 & 2,60 & 49,37 & 14,00 & 3,60 & 31,10 & 14,00 & 1,54 \\
M. gouazoubira M & 30,60 & 27,00 & 1,57 & 29,57 & 27,00 & 1,79 & 55,34 & 27,00 & 2,79 & 33,52 & 27,00 & 7,31 \\
M. nemorivaga $\mathbf{M}$ & 30,76 & 14,00 & 0,94 & 31,00 & 14,00 & 1,40 & 50,92 & 14,00 & 3,54 & 32,20 & 14,00 & 1,15 \\
AllGroups & 30,21 & 87,00 & 1,69 & 29,82 & 87,00 & 2,37 & 53,01 & 87,00 & 3,96 & 32,43 & 87,00 & 5,78
\end{tabular}

\begin{tabular}{lccrcccccccccc}
\hline \multicolumn{1}{c}{ Variables } & GBPP & GBPP & GBPP & GBFM & GBFM & GBFM & HFM & HFM & HFM & GBBC & GBBC & GBBC \\
& Means & \multicolumn{1}{c}{$n$} & \multicolumn{1}{c}{ s.d. Means } & \multicolumn{1}{c}{$n$} & s.d. & Means & $n$ & s.d. & Means & $n$ & s.d. \\
\hline M. gouazoubira F & 43,47 & 32,00 & 14,65 & 16,72 & 32,00 & 3,55 & 16,31 & 32,00 & 3,48 & 54,41 & 32,00 & 4,42 \\
M. nemorivaga F & 43,66 & 14,00 & 3,08 & 15,59 & 14,00 & 1,21 & 16,20 & 14,00 & 1,88 & 51,66 & 14,00 & 2,88 \\
M. gouazoubira M & 45,71 & 27,00 & 13,59 & 16,73 & 27,00 & 3,68 & 15,60 & 27,00 & 4,80 & 56,55 & 27,00 & 3,43 \\
M. nemorivaga M & 45,54 & 14,00 & 2,29 & 17,31 & 14,00 & 1,54 & 17,71 & 14,00 & 1,32 & 54,28 & 14,00 & 2,99 \\
AllGroups & 44,53 & 87,00 & 11,69 & 16,64 & 87,00 & 3,08 & 16,30 & 87,00 & 3,55 & 54,61 & 87,00 & 3,98
\end{tabular}

\begin{tabular}{|c|c|c|c|c|c|c|c|c|c|c|c|c|}
\hline Vari & LFBO & LFBO & LFBO & GBAO & GBAO & GBAO & LBBO & LBBO & LBBO & $\mathrm{ZYB}$ & ZYB & ZYB \\
\hline & Means & $n$ & s.d. & Means & $n$ & s.d. & Means & $n$ & s.d. & Means & $n$ & s.d. \\
\hline M.gouazoubira F & 49,41 & 32,00 & 3,67 & 64,62 & 32,00 & 11,52 & 28,41 & 32,00 & 6,92 & 74,94 & 32,00 & 15,09 \\
\hline M.nemorivaga $\mathbf{F}$ & 47,58 & 14,00 & 1,76 & 53,08 & 14,00 & 8,21 & 33,72 & 14,00 & 9,99 & 71,93 & 14,00 & 5,57 \\
\hline M.gouazoubira M & 4,11 & 27,00 & 4,49 & 66,86 & 27,00 & 17,17 & 28,81 & 27,00 & 4,62 & 72,78 & 27,00 & 23,51 \\
\hline M.nemorivaga $\mathbf{M}$ & 51,72 & 14,00 & 2,90 & 58,12 & 14,00 & 6,10 & 36,14 & 14,00 & 1,68 & 62,02 & 14,00 & 26,58 \\
\hline AllGroups & 50,94 & 87,00 & 4,32 & 62,41 & 87,00 & 13,34 & 30,63 & 87,00 & 6,97 & 71,70 & 87,00 & 19,50 \\
\hline
\end{tabular}

\begin{tabular}{|c|c|c|c|c|c|c|c|c|c|c|c|c|}
\hline Va & GBN & GBN & GBN & GBPM & GBPM & GBPM & BNUCR & BNUCR & BNUCR & CBURR & CBURR & CBURR \\
\hline & Means & $n$ & s.d. & Means & $n$ & s.d. & Means & $n$ & s.d. & Means & $n$ & s.d. \\
\hline I.gouazoubira F & 17,81 & 32,00 & 5,00 & 18,58 & 32,00 & 2,39 & 44,61 & 32,00 & 3,83 & 0,00 & 32,00 & 0,00 \\
\hline M.nemorivaga $\mathbf{F}$ & 15,26 & 13,00 & 7,76 & 16,47 & 14,00 & 5,43 & 42,22 & 14,00 & 2,57 & 0,00 & 14,00 & 0,00 \\
\hline M.gouazoubira $\mathbf{M}$ & 20,11 & 27,00 & 2,83 & 18,44 & 27,00 & 4,25 & 42,50 & 27,00 & 12,72 & 12,47 & 27,00 & 4,75 \\
\hline M.nemorivaga $\mathbf{M}$ & 16,81 & 14,00 & 6,06 & 15,86 & 14,00 & 7,05 & 43,42 & 14,00 & 2,14 & 12,58 & 14,00 & 2,19 \\
\hline AllGroups & 17,98 & 86,00 & 5,34 & 17,76 & 87,00 & 4,55 & 43,38 & 87,00 & 7,55 & 5,90 & 87,00 & 6,86 \\
\hline
\end{tabular}

